NASA/TM-2013-217834

\title{
Performance Gains of Propellant Management Devices for Liquid Hydrogen Depots
}

Jason W. Hartwig

ZIN Technologies, Brook Park, Ohio

John B. McQuillen and David J. Chato

Glenn Research Center, Cleveland, Ohio 


\section{NASA STI Program . . . in Profile}

Since its founding, NASA has been dedicated to the advancement of aeronautics and space science. The NASA Scientific and Technical Information (STI) program plays a key part in helping NASA maintain this important role.

The NASA STI Program operates under the auspices of the Agency Chief Information Officer. It collects, organizes, provides for archiving, and disseminates NASA's STI. The NASA STI program provides access to the NASA Aeronautics and Space Database and its public interface, the NASA Technical Reports Server, thus providing one of the largest collections of aeronautical and space science STI in the world. Results are published in both non-NASA channels and by NASA in the NASA STI Report Series, which includes the following report types:

- TECHNICAL PUBLICATION. Reports of completed research or a major significant phase of research that present the results of NASA programs and include extensive data or theoretical analysis. Includes compilations of significant scientific and technical data and information deemed to be of continuing reference value. NASA counterpart of peer-reviewed formal professional papers but has less stringent limitations on manuscript length and extent of graphic presentations.

- TECHNICAL MEMORANDUM. Scientific and technical findings that are preliminary or of specialized interest, e.g., quick release reports, working papers, and bibliographies that contain minimal annotation. Does not contain extensive analysis.

- CONTRACTOR REPORT. Scientific and technical findings by NASA-sponsored contractors and grantees.
- CONFERENCE PUBLICATION. Collected papers from scientific and technical conferences, symposia, seminars, or other meetings sponsored or cosponsored by NASA.

- SPECIAL PUBLICATION. Scientific, technical, or historical information from NASA programs, projects, and missions, often concerned with subjects having substantial public interest.

- TECHNICAL TRANSLATION. Englishlanguage translations of foreign scientific and technical material pertinent to NASA's mission.

Specialized services also include creating custom thesauri, building customized databases, organizing and publishing research results.

For more information about the NASA STI program, see the following:

- Access the NASA STI program home page at http://www.sti.nasa.gov

- E-mail your question to help@sti.nasa.gov

- Fax your question to the NASA STI Information Desk at 443-757-5803

- Phone the NASA STI Information Desk at 443-757-5802

- Write to: STI Information Desk NASA Center for AeroSpace Information 7115 Standard Drive Hanover, MD 21076-1320 
NASA/TM-2013-217834

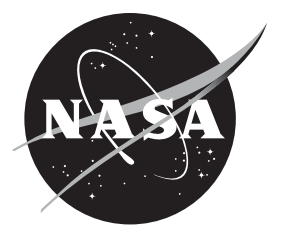

\section{Performance Gains of Propellant Management Devices for Liquid Hydrogen Depots}

Jason W. Hartwig

ZIN Technologies, Brook Park, Ohio

John B. McQuillen and David J. Chato

Glenn Research Center, Cleveland, Ohio

Prepared for the

51st Aerospace Science Conference

sponsored by the American Institute of Aeronautics and Astronautics

Grapevine, Texas, January 7-19, 2013

National Aeronautics and

Space Administration

Glenn Research Center

Cleveland, Ohio 44135 


\section{Acknowledgments}

This work was funded by the Cryogenic Propellant Storage and Transfer Project under the Office of the Chief Technologist at NASA.

Trade names and trademarks are used in this report for identification only. Their usage does not constitute an official endorsement, either expressed or implied, by the National Aeronautics and Space Administration.

Level of Review: This material has been technically reviewed by technical management.

Available from

NASA Center for Aerospace Information 7115 Standard Drive

Hanover, MD 21076-1320
National Technical Information Service 5301 Shawnee Road Alexandria, VA 22312

Available electronically at http://www.sti.nasa.gov 


\title{
Performance Gains of Propellant Management Devices for Liquid Hydrogen Depots
}

\author{
Jason W. Hartwig \\ ZIN Technologies \\ Brook Park, Ohio 44142 \\ John B. McQuillen and David J. Chato \\ National Aeronautics and Space Administration \\ Glenn Research Center \\ Cleveland, Ohio 44135
}

\begin{abstract}
This paper presents background, experimental design, and preliminary experimental results for the liquid hydrogen bubble point tests conducted at the Cryogenic Components Cell 7 facility at the NASA Glenn Research Center in Cleveland, Ohio. The purpose of the test series was to investigate the parameters that affect liquid acquisition device (LAD) performance in a liquid hydrogen $\left(\mathrm{LH}_{2}\right)$ propellant tank, to mitigate risk in the final design of the LAD for the Cryogenic Propellant Storage and Transfer Technology Demonstration Mission, and to provide insight into optimal LAD operation for future $\mathrm{LH}_{2}$ depots. Preliminary test results show an increase in performance and screen retention over the low reference $\mathrm{LH}_{2}$ bubble point value for a $325 \times 2300$ screen in three separate ways, thus improving fundamental $\mathrm{LH}_{2} \mathrm{LAD}$ performance. By using a finer mesh screen, operating at a colder liquid temperature, and pressurizing with a noncondensible pressurant gas, a significant increase in margin is achieved in bubble point pressure for $\mathrm{LH}_{2}$ screen channel LADs.
\end{abstract}

\section{Nomenclature}

$D_{p} \quad$ pore diameter $(\mu \mathrm{m})$

DPT differential pressure transducer

FTS flow through screen

g gravitational acceleration $\left(\mathrm{m} / \mathrm{s}^{2}\right)$

GHe gaseous helium

$\mathrm{GH}_{2} \quad$ gaseous hydrogen

$\mathrm{GN}_{2} \quad$ gaseous nitrogen

GRC NASA Glenn Research Center

IPA isopropyl alcohol

LAD liquid acquisition device

$\mathrm{LCH}_{4} \quad$ liquid methane

LEO low Earth orbit

$L L \quad$ liquid level above LAD screen (m)

$\mathrm{LN}_{2} \quad$ liquid nitrogen

LOX liquid oxygen

$\mathrm{L} / \mathrm{V} \quad$ liquid/vapor

MAWP maximum allowable working pressure

$\mathrm{MMH}$ monomethyl hydrazine

$\mathrm{N}_{2} \mathrm{O}_{4} \quad$ nitrous tetraoxide

NBP normal boiling point

OMS Orbital Maneuvering System

PID proportional-integral-derivate 


$\begin{array}{ll}\text { PMD } & \text { propellant management devices } \\ \text { RCS } & \text { Reaction Control System } \\ \text { RD } & \text { receiver dewar } \\ \text { SD } & \text { silicon diode } \\ \text { STS } & \text { Shuttle Space Transportation Systems } \\ \text { TRL } & \text { technology readiness level } \\ \text { VJ } & \text { vacuum jacketed } \\ \Delta P_{B P} & \text { bubble point pressure }(\mathrm{Pa}) \\ \Delta P_{\text {dynamic }} & \text { pressure loss for mass accumulation along channel length }(\mathrm{Pa}) \\ \Delta P_{F T S} & \text { pressure loss for flow through screen }(\mathrm{Pa}) \\ \Delta P_{\text {friction }} & \text { friction pressure loss for flow along channel }(\mathrm{Pa}) \\ \Delta P_{\text {hydrostatic }} & \text { hydrostatic pressure }(\mathrm{Pa}) \\ \Delta P_{\text {other }} & \text { other sources of pressure fluctuations and differences }(\mathrm{Pa}) \\ \gamma & \text { surface tension (mN } / \mathrm{m}) \\ \rho_{\mathrm{LH}} & \text { liquid hydrogen density }\left(\mathrm{kg} / \mathrm{m}^{3}\right) \\ \theta_{c} & \text { contact angle (degrees) }\end{array}$

\subsection{Introduction}

In recent years, there has been a decline in the proposed usage of toxic propellants, such as nitrous tetraoxide $\left(\mathrm{N}_{2} \mathrm{O}_{4}\right)$ and monomethyl hydrazine $(\mathrm{MMH})$. Safety and environmental concerns over the use of these storable propellants (propellants that are liquids at room temperature) have led to the ongoing examination of non-toxic cryogenic propellants as an ideal fluid for on-orbit propulsion systems for future human and robotic exploration missions. Among the available choices, liquid oxygen/liquid hydrogen $\left(\mathrm{LOX} / \mathrm{LH}_{2}\right)$ is the propellant combination of choice owing to an unmatched level of performance relative to other systems. In addition, $\mathrm{LOX} / \mathrm{LH}_{2}$ has proven flight heritage in launch systems such as Saturn V (S4, S4B, S2) and Shuttle Space Transportation Systems (STS), as well as short duration upper stages (Centaur, Delta IV). $\mathrm{LOX} / \mathrm{LH}_{2}$ is also an attractive candidate for proposed future in-space engines like the $\mathrm{J}-2 \mathrm{X}$, and low Earth orbit (LEO) fuel depots, both of which are required to enable long duration space missions (Kutter et al. 2008, Kutter 2010, and McLean et al. 2011). However in the optimal design of any spacecraft, high performance is not the only consideration. Long term missions will require either a reconsideration of propellant choice or a refinement of existing $\mathrm{LOX} / \mathrm{LH}_{2}$ technology.

There are challenging aspects when working with cryogenic liquid hydrogen due to its thermophysical properties. The low liquid density and normal boiling point (NBP) makes $\mathrm{LH}_{2}$ difficult to package, requiring larger storage tanks. Hydrogen's critical temperature and pressure limits the conditions under which hydrogen exists as a liquid. $\mathrm{LH}_{2}$ is particularly susceptible to parasitic heat leak due to its low NBP resulting in propellant loss due to boil off. Finally, it is difficult to transfer and maintain single phase liquid flow due to its low viscosity, NBP, and surface tension, making vapor ingestion into the transfer line highly probable.

Gravity affects many fluidic processes, such as the separation of liquid and vapor within a propellant tank. In 1-g, density controls the location of the liquid/vapor (L/V) interface, as the heavier liquid settles to the bottom and lighter vapor rises to the top. In low Bond number (ratio of gravitational to surface tension forces) environments, surface tension controls the location of the $\mathrm{L} / \mathrm{V}$ interface because liquid tends towards the walls and vapor tends towards the center of the tank. A robust, flexible system capable of delivering single phase liquid flow in varying gravitational and thermal environments is clearly required to meet the demands of both future in-space engines as well as the proposed fuel depots. 


\subsection{Screen Channel LADs}

When transferring propellant in microgravity either by pump or pressure fed applications, it is necessary to transport only single phase liquid to an engine to ensure efficient thermal conditioning of the engine and reliable operation after ignition. Depot tanks will also require high liquid fill fractions due to the projected cost of launching and storing propellant in LEO. In Earth's 1-g field or in milli-g environments, propellant transfer is fairly simple. Single phase liquid flow is ensured by an antivortex baffle to prevent gas ingestion into the tank outlet. Fluid is transferred by pressurizing the tank and opening a valve at the bottom of the tank. In microgravity however, liquid may not sufficiently cover the tank outlet making single phase liquid expulsion a challenge.

The need for a special device to separate liquid and gas in cryogenic propellant tanks was required to perform engine restarts in a low-g environment (Radcliffe and Transue 1961). Depending on the gravitational environment and mission requirements, a variety of propellant management devices (PMD) may be required to favorably position the liquid and/or ullage in the tank. One type of PMD, a screen channel LAD, uses surface tension forces to acquire and maintain single phase flow to the transfer line.

These LADs are designed and manufactured in a variety of styles, sizes, and geometries. In flight-like systems, screen channels, or gallery arms, tend to closely follow the contour of the propellant tank wall (shown in Figure 1) and can have different cross section geometries (typically a triangular or rectangular shape). The channel side that faces the wall has openings covered with a tightly woven fine mesh screen. The screen has micron sized pores which are used to wick liquid into the channel, prevent pores from drying out during tank drain, and also act as a barrier to vapor ingestion. As liquid is withdrawn from the tank and vapor approaches the screen, surface tension forces at the screen generate a localized area of high pressure differential that blocks vapor entrance into the channel, but allow the liquid to flow freely. Liquid is wicked along the screen and prevents the pores from drying out if they come into contact with vapor. Full communication LADs (i.e., LAD that extends the entire height of the tank wall to maintain communication with the liquid at all time) have demonstrated flight heritage in storable systems such as the STS Reaction Control System (RCS) and Orbital Maneuvering System (OMS) (Fester et al. 1975 and Peterson and Uney 1978) and the design of LADs for storables is well understood (Schweickert 1981 and Anglim 1981). Although screen channel LADs have been used in a small scale liquid helium experiment in microgravity (Anderson 1989), they have not been used with $\mathrm{LH}_{2}$ in low gravity.

Vane and sponge type PMDs can provide vapor-free liquid under a much simpler design and implementation (Jaekle 1991, 1993, 1997) than screen channel LADs. Both types are advantageous in systems which experience low-g levels and very low supply demands. However, sponges and vanes may not meet the high flow rate requirements of future propellant depots; sponges simply do not scale with the projected size of depot tanks, and vanes may not be able to supply large flow rates relative to screen channel LADs. Thus, screen channel LADs may be the most extensible and flexible cryogenic propellant management device for variable vehicle acceleration and direction, and provide a wide range of flow rate regimes to supply single phase liquid for both engine restart and continuous engine operation, as well as fluid transfer for fuel cells, life support, and the proposed fuel depots.

For flight systems, screen channel LAD usage is broken into two categories (Burge and Blackmon 1973 and Burge et al. 1973). Start baskets, traps, and start tanks are considered small, liquid acquisition devices that confine sufficient liquid to start engines until the relatively large accelerations can adequately reorient the liquid for the large flow rates required for engine operation. Meanwhile full communication channels, distributers, or tank liners are used in systems with small accelerations and flows rates.

The choice of screen for the LAD is dictated by the gravitational environment and desired maximum flow rate, which can be estimated through knowledge of the bubble point pressure (Section 3.0). Screens are characterized by the screen weave, which refers to the number of wires per inch in each direction, and the specific weave pattern used during manufacturing. For example, the $325 \times 2300$ Dutch Twill mesh screen displayed in Figure 2 has 325 warp wires and 2300 shute wires per square inch of the screen. For a Dutch Twill, each shute wire passes under two warp wires before traveling over the next two warp wires. Fine mesh Dutch Twill screens create very small pores and provide a tortuous path and resistance against 


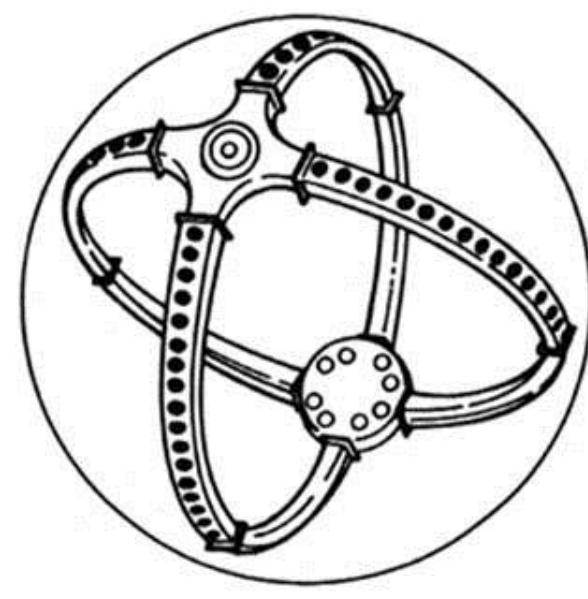

Figure 1.-Full Communication Screen Channel LAD.

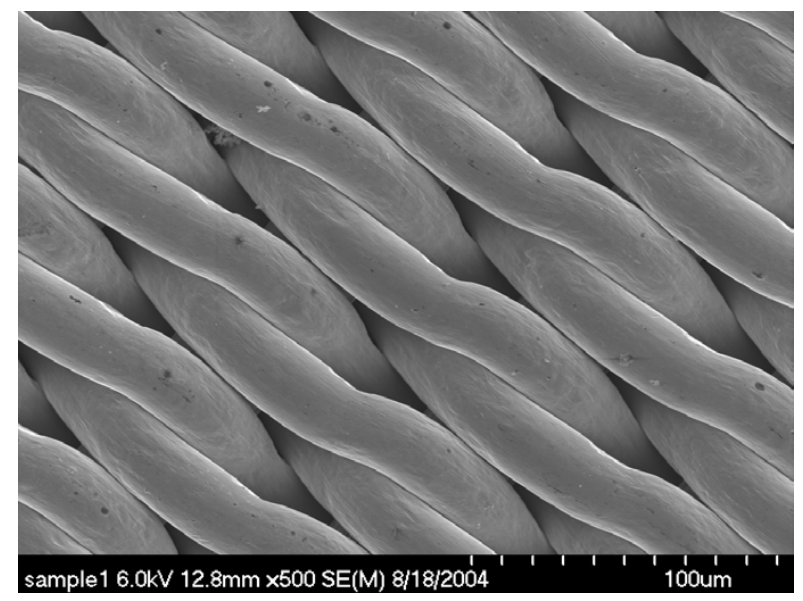

Figure 2.-Scanning electron microscope image of a $325 \times 2300$ screen sample.

gas ingestion, which make them popular choices for low surface tension cryogenic liquids. However they tend to generate large hydraulic pressure losses during outflow and may become clogged by particulate matter. Therefore, no single screen mesh or style exists to optimize the PMD for all propellant tanks and missions.

\subsection{The Bubble Point}

The primary performance parameter characterizing LADs is the bubble point, which is defined as the differential pressure required to overcome the liquid surface tension force at the screen pore. Physical parameters that affect the bubble point include the geometry and size of the screen pore, the contact angle between screen pore and fluid, and the fluid surface tension. Hartwig and Mann (2013a) derived a bubble point model based on room temperature bubble point tests:

$$
\Delta P_{B P}=\frac{4 \gamma \cos \theta_{C}}{D_{P}}
$$

where $\gamma$ is the surface tension of the fluid $(\mathrm{mN} / \mathrm{m}), \theta_{C}$ is the contact angle between liquid propellant and solid screen pore, and $D_{P}$ is the average pore diameter $(\mu \mathrm{m})$. Based on previously reported cryogenic bubble points from Hartwig and McQuillen (2011 and 2012a), the model is only valid for normally saturated liquids. Hartwig and Mann (2013b) showed that Equation (1) simplifies to

$$
\Delta P_{B P}=\frac{4 \gamma}{D_{P}}
$$

for cryogenic liquids. Effective pore diameters can be determined from room temperature bubble point tests conducted in high surface tension liquids (relative to cryogenic liquids) such as isopropyl alcohol (IPA).

To prevent vapor ingestion into the channel during outflow, the total pressure loss in the LAD system must be less than the bubble point pressure:

$$
\Delta P_{\text {total }}<\Delta P_{B P}
$$

where the total pressure loss is expressed as:

$$
\Delta P_{\text {total }}=\Delta P_{\text {hydrostatic }}+\Delta P_{F T S}+\Delta P_{\text {friction }}+\Delta P_{\text {dynamic }}+\Delta P_{\text {other }}
$$


where $\Delta P_{\text {hydrostatic }}$ is the hydrostatic pressure within the channel, $\Delta P_{F T S}$ is the pressure drop across the screen, $\Delta P_{\text {friction }}$ is the frictional loss down the LAD channel, $\Delta P_{\text {dynamic }}$ is the dynamic pressure drop due to inflow into the channel, and $\Delta P_{\text {other }}$ is the pressure loss contribution due to vibrations, propellant sloshing, and/or transients (Van Dyke 1998). For the orbital conditions of LEO, pressure losses due to flow through screen (FTS) and transients become leading order effects. For a given LAD screen, cryogenic liquid, operating range of liquid temperature, pressure, and mass flow, the bubble point thus serves as an upper limit on the total allowable pressure loss for that system. Since the bubble point is easily measurable and readily translated into a deliverable flow rate to an engine or depot receiver tank, it serves as the primary performance parameter for characterizing any screen channel LAD.

\subsection{Test Objectives}

Issues that arise in $\mathrm{LH}_{2}$ cryogenic fluid management can be generically categorized into storage and transfer and are being addressed through a suite of ground testing at NASA as part of its technology maturation program. To address transfer issues, both a small scale component level bubble point test and a full scale screen channel LAD test are being performed at NASA Glenn Research Center (GRC). The preliminary bubble point test results are reported here. The purpose of this test was threefold: to give future mission designers insight into the influential factors that govern LAD behavior, to mitigate risk in flight LAD design/operation, and to demonstrate improved screen retention using three separate methods. Doing so will raise the technology readiness level (TRL) of $\mathrm{LH}_{2} \mathrm{LADs}$ for all future $\mathrm{LH}_{2}$ fueled propulsion systems and proposed cryogenic depots, and provide critical data for the mission designers.

\subsection{Performance Gains}

The current state of $\mathrm{LH}_{2}$ screen channel LADs technology is ascertained through detailed review of the literature. As was mentioned earlier, screen channel LADs have proven flight heritage with storable propellants, but, only ground testing has been conducted for cryogenic $\mathrm{LOX}$ and $\mathrm{LH}_{2}$ using these fine mesh screens. Previously reported bubble points for the most popular $325 \times 2300$ mesh screen are plotted in Figure 3, which includes data for $\mathrm{LH}_{2}$, liquid nitrogen $\left(\mathrm{LN}_{2}\right)$, $\mathrm{LOX}$, liquid methane $\left(\mathrm{LCH}_{4}\right)$ and IPA from Paynter (1973), Burge and Blackmon (1973), Cady (1973, 1975, 1977), Chato and Kudlac (2002), Kudlac and Jurns (2006), and Jurns et al. (2007), respectively. The black line is the predicted values using Equation (2) and a pore diameter specified from Hartwig and Mann (2013a). Figure 4 plots sparse historical data for the finer $450 \times 2750$ mesh screen. Chronologically, a considerable amount of $\mathrm{LH}_{2} \mathrm{LAD}$ ground testing was performed in the early 1970s as part of the STS auxiliary and Centaur upper stage propulsion systems. $\mathrm{LH}_{2} \mathrm{LAD}$ work progressed into the 1990 s as part of technology development for propellant transfer vehicles and the Space Station Freedom. In the 2000s, a single bubble point measurement in $\mathrm{LH}_{2}$ was conducted at GRC by Chato and Kudlac (2002).

The resultant NBP $\mathrm{LH}_{2}$ bubble point value at atmospheric pressure for the $325 \times 2300$ screen is only $520 \mathrm{~Pa}$. There was reported difficulty in even resealing the coarser $200 \times 1400$ screen after bubble breakthrough from Chato and Kudlac (2002). Since the bubble point serves as the upper limit on allowable pressure loss in a flight LAD, this low value severely limits the operating flow rates and liquid temperature. Over time, the liquid in the tank absorbs heat from the environment, the surface tension and thus bubble point will only decrease with increasing liquid temperature. Given this low baseline reference level, it was necessary to seek ways to improve the fundamental performance of $\mathrm{LH}_{2} \mathrm{LADs}$.

There are three ways to increase margin in the bubble point over the baseline $325 \times 2300$ value. First, choosing a finer mesh screen can theoretically decrease the effective pore diameter. While the $325 \times 2300$ has been extensively used in ground tests, data is available in the literature for a finer $450 \times 2750$ mesh screen and the data is plotted in Figure 4. Burge et al. (1972) and Cady (1973) report $\mathrm{LH}_{2}$ data while Castle (1972) reports $\mathrm{LN}_{2}$ and IPA data for this finer mesh screen. The black curve in Figure 4 is based on room temperature bubble point tests from Hartwig and Mann (2013a). As shown, for both room temperature and cryogenic fluids, higher bubble points can be obtained using the 450 screen. 


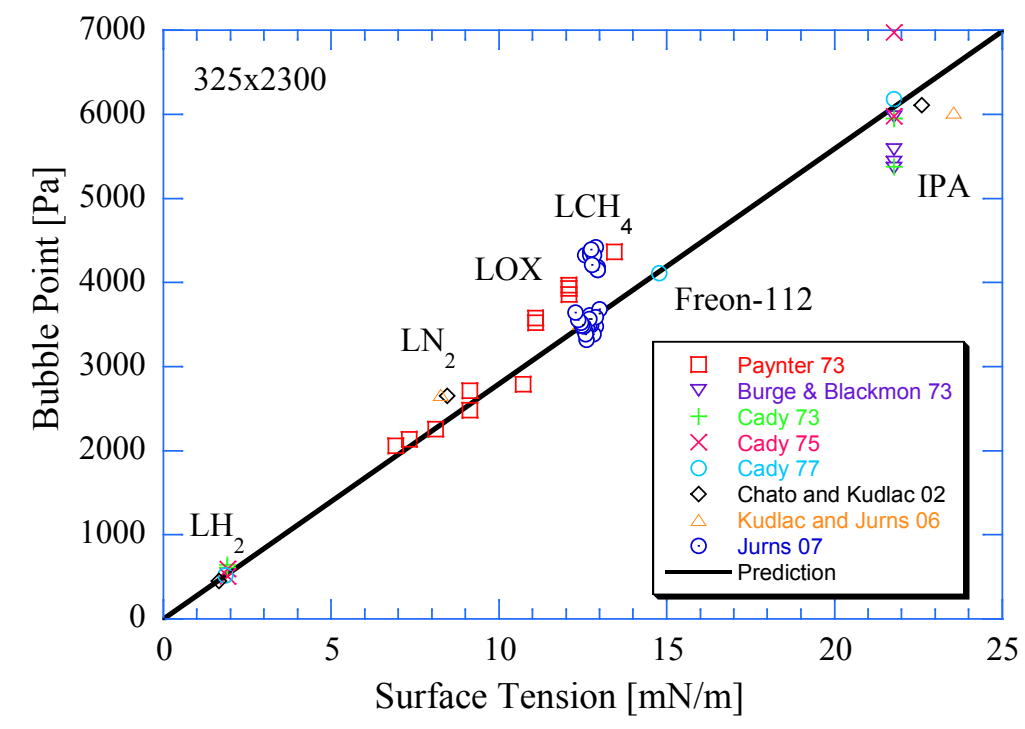

Figure 3.-Previously reported $\mathrm{LH}_{2}$ bubble point values for the $325 \times 2300$ Dutch Twill screen with helium pressurant.

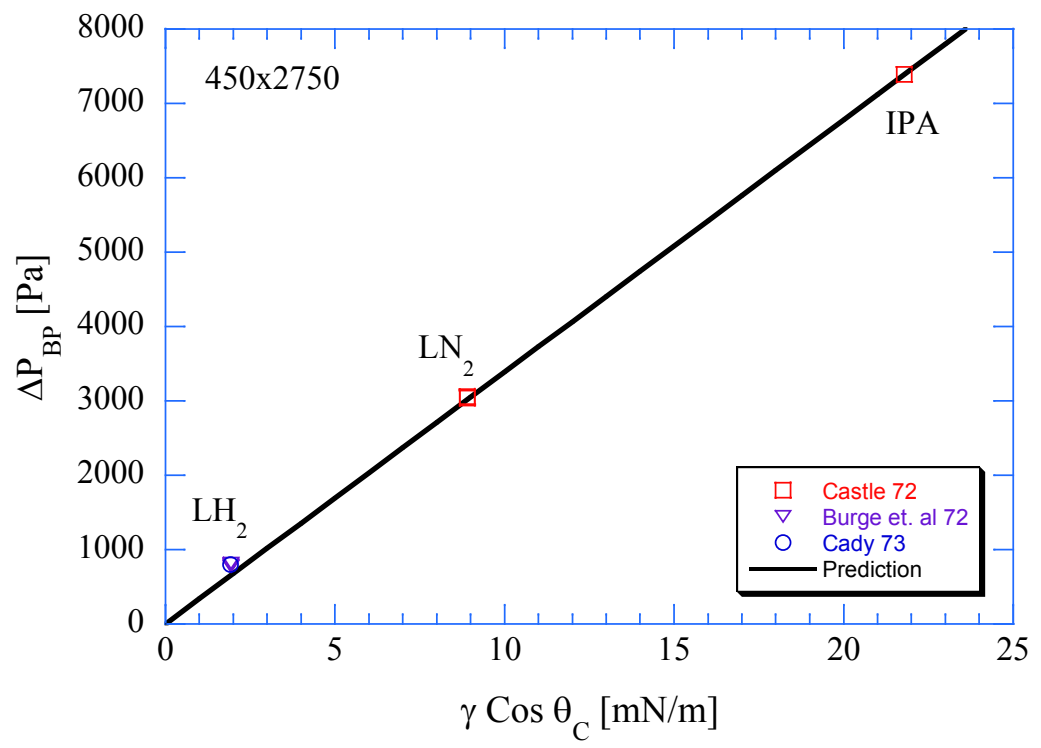

Figure 4.-Previously reported bubble point values for the $450 \times 2750$ Dutch Twill screen with helium pressurant.

Secondly, one can improve bubble point margin by obtaining a colder liquid temperature, since surface tension, and thus bubble point, is an inverse function of temperature. Third, the margin can be increased by subcooling the liquid with a noncondensible pressurant such as gaseous helium (GHe). Previous tests with LOX and LCH4 demonstrated an increase in margin, but this effect must be confirmed with $\mathrm{LH}_{2}$. With such a small baseline reference value, any excess bubble point margin counts when working with $\mathrm{LH}_{2}$ LADs.

\subsection{Experimental Setup}

Testing was performed at the Cryogenic Components Lab 7 (CCL-7) at GRC in Cleveland, Ohio. The same samples from Hartwig and Mann (2012a and b) were tested here. Figure 5 shows the LAD screen 
and cup assembly. Each $6.35 \mathrm{~cm}$ (2.5 in.) screen sample was welded onto a custom built flange with a cover ring and fillet weld to prevent leakage along the screen edges. Testing was always performed in an inverted configuration, with liquid above the screen and vapor or gas below the screen. Therefore, the purpose of the cup was to create the $\mathrm{L} / \mathrm{V}$ interface within the screen pores by pressurizing the screen from below. Gas was distributed uniformly inside the cup by a custom built cross shaped manifold. Threaded rods supported an aluminized mirror to reflect an image of the top of the LAD screen as shown in Figure 5. The rods were also used to mount a fiber optic light source.

The LAD screen/cup was mounted inside a receiver dewar (RD) as shown in Figure 6. The RD housed the $\mathrm{LH}_{2}$ on top of the LAD screen. The RD was equipped with seven ports for liquid fill and drain, vent (x2), power, light source, and instrumentation for both RD and LAD cup, and three side ports for pressurant gas fill, drain, and differential pressure transducer (DPT) measurements. The image of the LAD screen was reflected off the mirror and recorded through the side portal located halfway up the dewar wall. A camera mounted to the viewport viewed and recorded the LAD screen in real time. Images were time stamped to synchronize with all other data.

The $\mathrm{LH}_{2}$ (or $\mathrm{LN}_{2}$ ) supply line was first routed through a supply dewar, as shown in Figure 7. The purpose of the supply dewar was to condition the liquid cryogen for the RD. For these tests, the dewar itself was never filled with liquid; it was simply pumped down to 2 psia to minimize heat leak into the liquid feed line. Vacuum jacketed (VJ) lines connected the dewars in series.

Several facility modifications to the experimental hardware from Jurns et al. (2007) were required before flowing $\mathrm{LH}_{2}$ at Cell 7, and to ensure higher accuracy results over previous bubble point tests. All pressure control and regulation valves were changed to allow complete remote operation of Cell 7 .

Second, the flow system was modified to remotely flow three different pressurization gases beneath the screen: $\mathrm{GHe}$, gaseous nitrogen $\left(\mathrm{GN}_{2}\right)$, and gaseous hydrogen $\left(\mathrm{GH}_{2}\right)$. Third, the gas flow control system was modified to allow slower ramp rates in pressurization beneath the screen. Fourth, to improve upon accuracy of measurements from Hartwig and McQuillen (2012a), dual range high accuracy DPTs were installed to measure the differential pressure across the screen as shown in Figure 7. Fifth, smaller diameter, $3 \mathrm{~mm}$ (1/8 in.) sense lines were used to improve pressure signal response time. Sixth, extra silicon diodes were installed to resolve temperature close to the screen. Finally, a new data acquisition system was installed to resolve difficulties in synchronizing the pressure, temperature, and flow data with the video data.

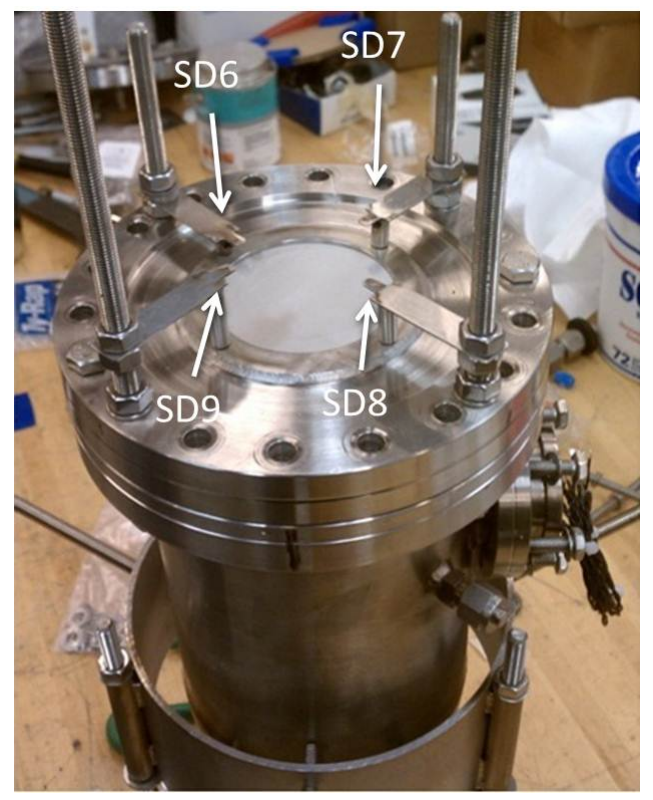

Figure 5.-LAD cup and diode rake. 


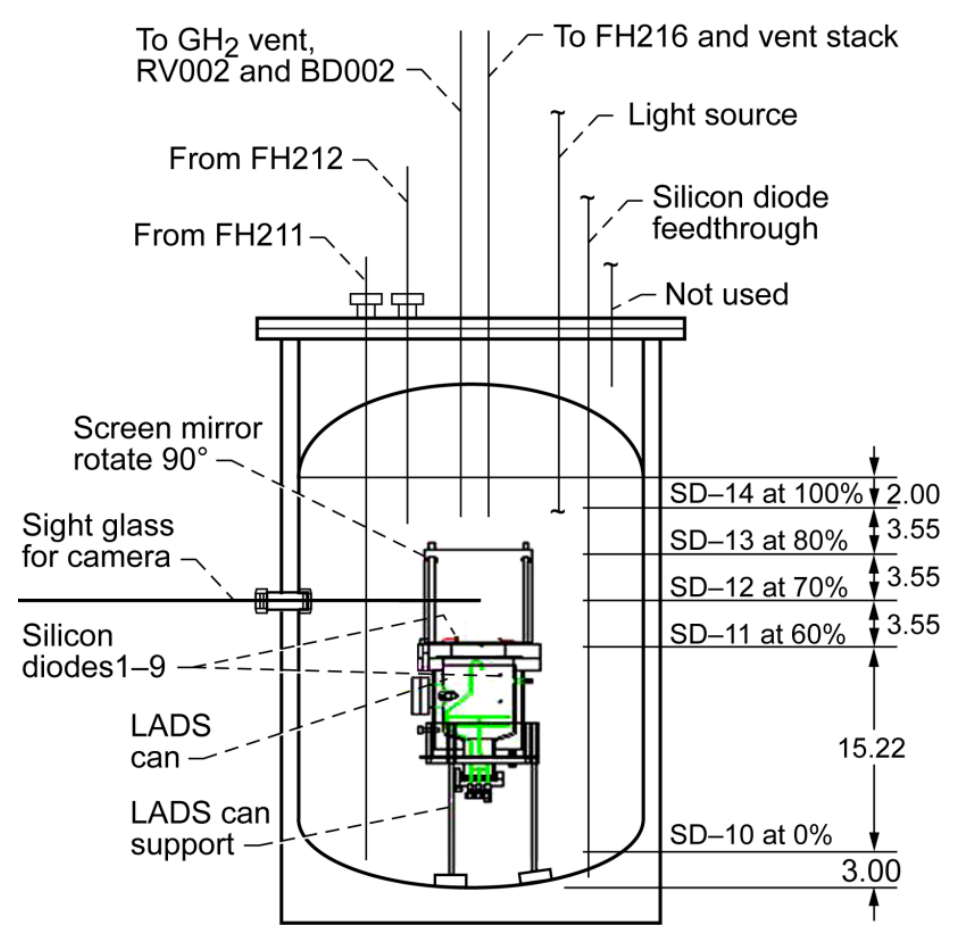

Figure 6.-Receiver dewar, temperature instrumentation.

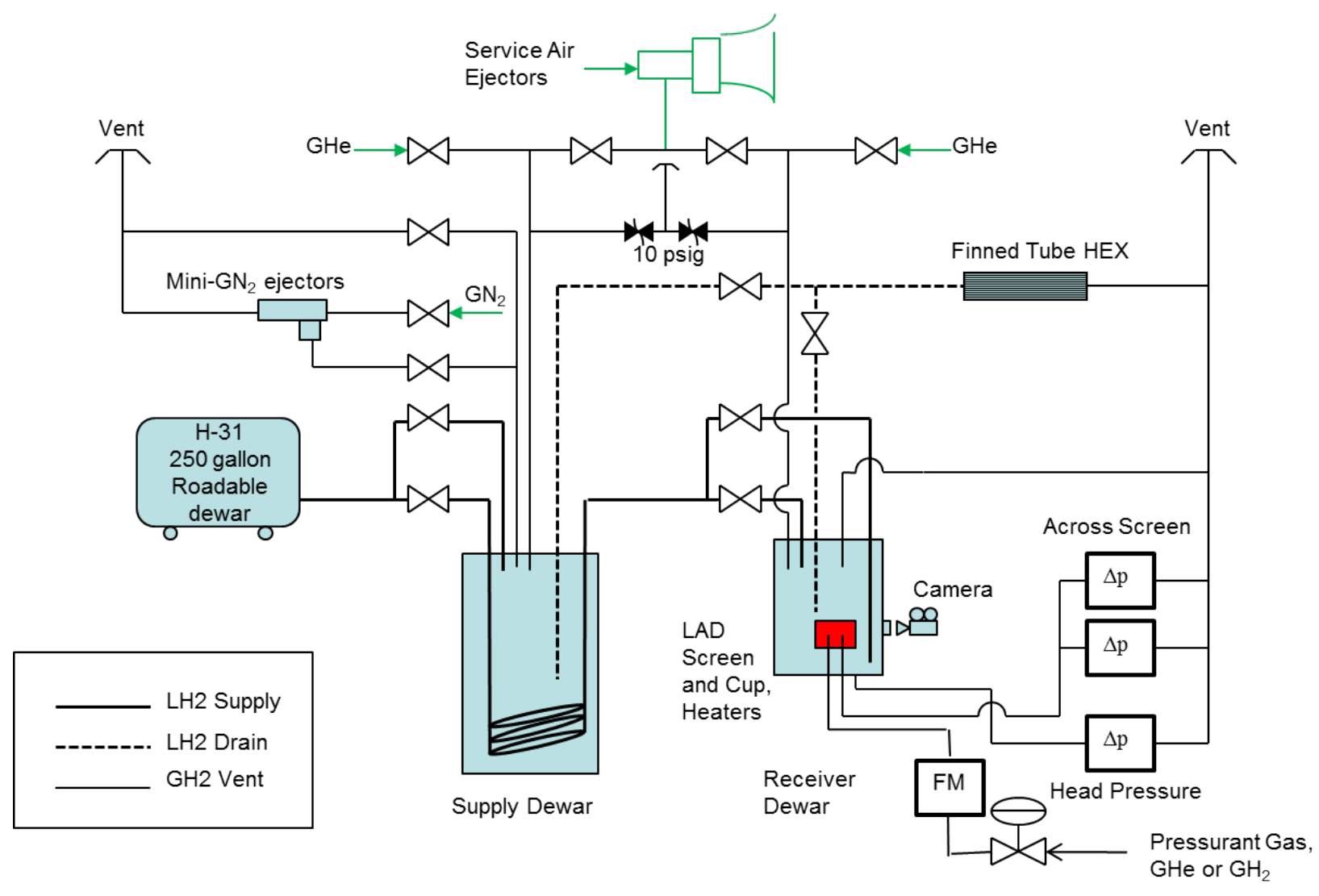

Figure 7.-Cell 7 Liquid Hydrogen Flow System. 
$\mathrm{LH}_{2}$ was filled offsite in portable 250 gal dewars and was connected to the flow system through a flexible VJ line. $\mathrm{LN}_{2}$ was connected through the same $\mathrm{VJ}$ line via a roadable 500 gal dewar, and was used to perform all pretest check outs and cold shocking of the hardware and to collect bubble point data. GHe was available from a portable tuber trailer while $\mathrm{GH}_{2}$ and $\mathrm{GN}_{2}$ were available from a high pressure Kbottle. Gas pressure and flow rate into the LAD cup were controlled by a set of three low flow control valves.

Liquid pressure inside the RD was primarily controlled using a proportional-integral-derivate (PID) loop. To increase pressure, gas was added to the ullage space in the RD. The pressure would also increase due to heat leak into the RD. The vent valve was opened to restore pressure back to ambient. To reduce pressures below atmospheric, Cell 7 ejectors were used to pump down on the liquid. Temperature of the $\mathrm{LH}_{2}$ was primarily controlled by initial conditioning of the liquid inside the roadable dewar. Cell 7 air ejectors were used to reduce the liquid temperature by reducing pressure in the ullage space. Parasitic heat leak into the RD provided more than sufficient thermal energy to increase liquid temperature. The pressure of the incoming pressurant gas was controlled by the set of flow control valves. The pressurant gas temperature was measured using a silicon diode (SD) located inside the cup (SD3) and controlled by heaters inside of the LAD cup, in a PID control loop.

Figure 5 and Figure 6 show the locations of temperature measurements. Diodes were mounted directly to the liquid (SD1) and gas (SD2) sides of the screen. Two diodes were mounted inside the LAD cup to measure the temperature of the incoming gas (SD3 and SD4). SD6-9 were mounted in a staircase as depicted in Figure 5 to resolve the temperature gradient in the bulk liquid above the LAD screen. SD10-14 provided temperature and liquid level inside the RD. Pressure was measured inside the LAD cup and in the RD. The differential pressure across the LAD screen was measured using a 0 to $1250 \mathrm{~Pa}$ ( 0 to 5 in $\left.\mathrm{H}_{2} \mathrm{O}\right)$ and 0 to $2500 \mathrm{~Pa}\left(0\right.$ to 10 in $\left.\mathrm{H}_{2} \mathrm{O}\right)$ high accuracy DPT while a 0 to $7500 \mathrm{~Pa}\left(0\right.$ to 30 in $\left.\mathrm{H}_{2} \mathrm{O}\right)$ DPT was used for $\mathrm{LN}_{2}$ bubble point tests. Gas flow rates into the cup were also measured.

Diodes measured temperature to within $\pm 0.1 \mathrm{~K}$. The pressure at the LAD screen was measured to within $2300 \mathrm{~Pa}(0.333 \mathrm{psia})$. The raw DPT reading across the screen was accurate to within $0.32 \mathrm{~Pa}$ $\left(0.0013\right.$ in $\mathrm{H}_{2} \mathrm{O}$ ), and the total uncertainty in reported bubble point pressures is estimated to be $2.3 \mathrm{~Pa}$ (0.093 in $\mathrm{H}_{2} \mathrm{O}$ ), which is less than 3.6 percent at the lowest measured pressures.

\subsection{Experimental Methodology}

The methodology for conducting the $\mathrm{LH}_{2}$ bubble point test was as follows. Prior to bubble point tests, all supply lines and both dewars were purged with GHe. A GHe flow was established across the LAD screen to prevent flooding of the cup during $\mathrm{LH}_{2}$ fill. Next, $\mathrm{LH}_{2}$ was transferred to condition the facility plumbing, $\mathrm{RD}$, and eventually fill the RD to the desired liquid level. Once the RD was filled, the liquid was conditioned to the desired temperature and pressure at the LAD screen using methods discussed earlier.

To conduct a bubble point test, the screen was resealed by slowly decreasing pressurant gas flow into the cup. The desired pressurant gas type and pressurant gas temperature was then selected. When switching over to autogenous pressurization, the vapor was allowed to flow through the lines, LAD cup, and screen for up to 10 minutes to purge other gases from inside the network prior to controlled bubble point tests. Then, the pressure underneath the LAD screen was slowly increased using the flow control valves. Eventually a bubble would break through the wetted screen, breaking the screen down, as indicated both by visual observation and an increase in the DPT signal. The bubble point was taken as the moment when a visible bubble penetrated the liquid laden screen. The time stamp at breakthrough was noted and synchronized to the data file to extract the corrected bubble point pressure and any other relevant parameters. Bubble point measurements were then repeated at similar pressures and/or temperatures for repeatability and consistency before moving on to the next data point. Note that bubbles broke through various locations on the screen, indicating that there was no preferential breakdown spot due to screen defects. 
Data reduction for the $\mathrm{LH}_{2}$ bubble point tests was straightforward. Details are presented in Hartwig and McQuillen (2012a). To compare with theoretical predictions, all experimental bubble point values were corrected for head pressure:

$$
\left.\Delta P_{B P}(T, P)\right|_{\exp }=D P T-\rho_{\mathrm{LH}_{2}} g L L
$$

where $L L$ is the liquid level above the screen in the RD as determined by the vertical silicon diode rake. Thermodynamic properties such as liquid density and surface tension were computed using REFPROP.

\subsection{Test Matrix}

The overall test plan is outlined on the left hand side in Figure 8. Three fine mesh screen channel LAD samples $(325 \times 2300,450 \times 2750,510 \times 3600)$ were tested in two cryogenic liquids $\left(\mathrm{LH}_{2}\right.$ and $\left.\mathrm{LN}_{2}\right)$, using two pressurization schemes (autogenous $\mathrm{GH}_{2} / \mathrm{LH}_{2}$ and $\mathrm{GN}_{2} / \mathrm{LN}_{2}$ and noncondensible $\mathrm{GHe} / \mathrm{LH}_{2}$ and $\mathrm{GHe} / \mathrm{LN}_{2}$ ) at several different pressurant gas temperatures. Bubble point data was collected across the widest possible range of liquid temperatures and pressures within facility limitations. The lower limit of data collection was limited by the Cell 7 ejector's ability to pull vacuum on the RD to chill the liquid to the saturation temperature at $31 \mathrm{kPa}$ (4.5 psia). The upper limit of $155 \mathrm{kPa}(22.5 \mathrm{psia})$ was dictated by the maximum allowable working pressure (MAWP) of the RD. This range allowed independent examination of both liquid temperature and pressure effects on bubble point using two different pressurant gases, as both saturated and subcooled liquid states were achievable. This is indicated in the blue shaded region in Figure 8. The pressure range corresponds to a range in $\mathrm{LH}_{2}$ temperatures of $16.7<\mathrm{T}<21.1 \mathrm{~K}$, which represents typical thermal conditions within a low pressure $\mathrm{LH}_{2}$ propellant tank. More bubble point data was collected during this test series than the sum total of all previous $\mathrm{LH}_{2} \mathrm{LADs}$ tests to date.

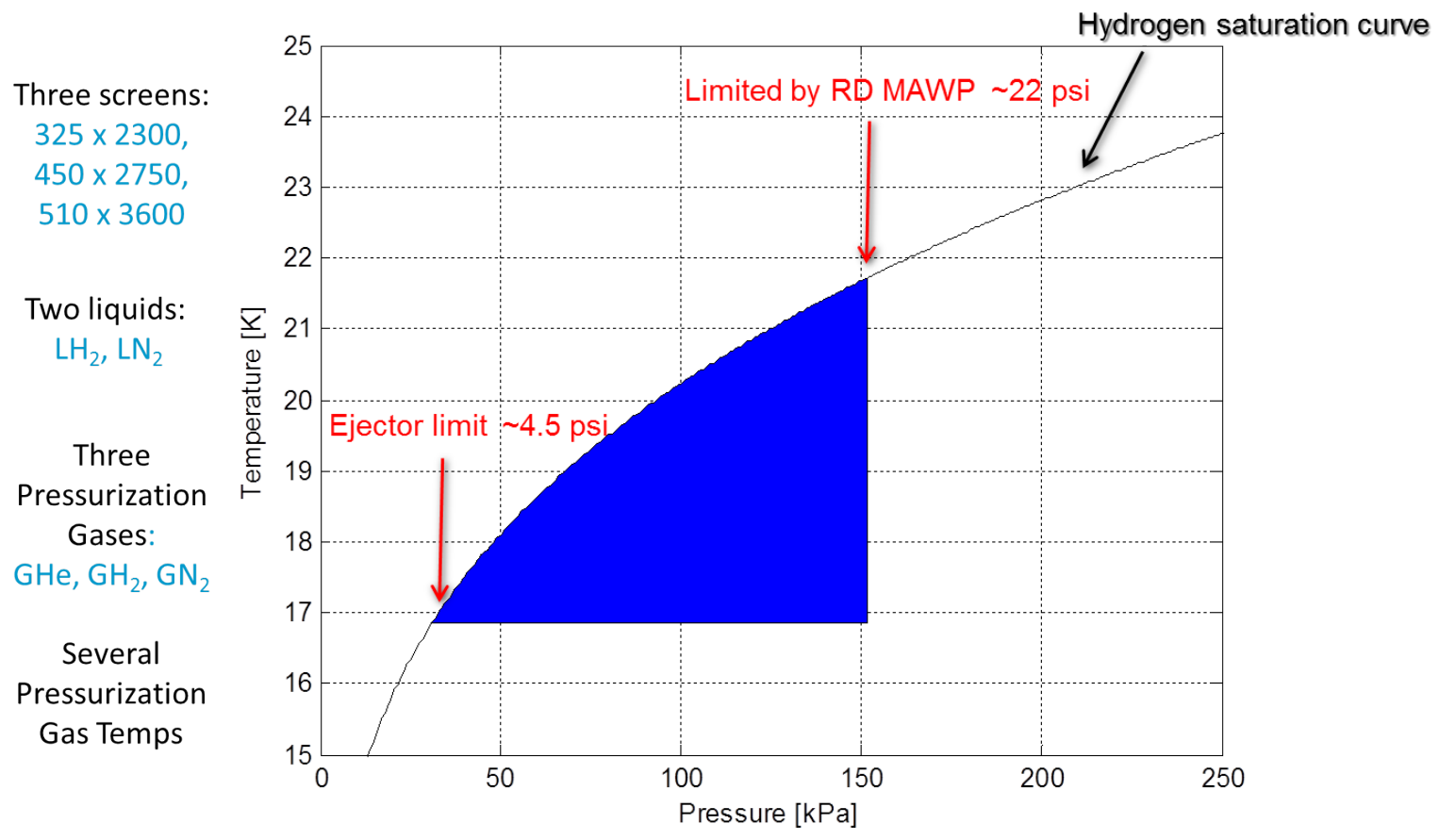

Figure 8.-LAD Bubble Point Test Plan. 
The test matrix for the $450 \times 2750$ screen in $\mathrm{LH}_{2}$ is outlined in Table I. Stable liquid temperature during testing permitted an isothermal marching scheme in data collection, as shown. For temperature variation, the blue shaded region in Figure 8 was divided into six equally spaced isothermal slices across the temperature range. For pressure variation, controlled breakthroughs were spaced in $6.9 \mathrm{kPa}(1.0 \mathrm{psi})$ intervals from the saturation pressure up to the MAWP. Data was collected across the entire range of liquid temperatures in Table I using both $\mathrm{GHe}$ and $\mathrm{GH}_{2}$ as pressurant gases. The pressurant gas feed line was immersed within the liquid inside the RD and the residence time of the gas inside the LAD cup was long enough such that the baseline gas temperature was approximately the liquid temperature. To collect data at elevated gas temperatures, the heaters inside the LAD cup were activated and the entire grid in Table I was repeated for two more pressurant gas temperatures. The entire process was repeated for the other two meshes. Parametric bubble point testing for both $\mathrm{LH}_{2}$ and $\mathrm{LN}_{2}$ required approximately 3 weeks of continuous testing with a total test time of approximately four months for cold shocks, check outs, testing, and screen change out.

TABLE I.-TEST MATRIX: $450 \times 2750$

\begin{tabular}{|c|c|c|c|c|c|c|c|c|c|c|c|c|c|c|c|c|c|c|c|c|}
\hline $\begin{array}{c}\mathrm{LH}_{2} \\
P_{\mathrm{SAT}}\end{array}$ & $\begin{array}{l}\mathrm{T}, \\
\mathrm{K}\end{array}$ & \multicolumn{19}{|c|}{$\begin{array}{c}P_{\text {SCREEN }}, \\
\text { psia }\end{array}$} \\
\hline $29.3(4.25)$ & 16.7 & 4.25 & 5 & 6 & 7 & 8 & 9 & 10 & 11 & 12 & 13 & 14 & 15 & 16 & 17 & 18 & 19 & 20 & 21 & 22 \\
\hline $41.4(6)$ & 17.5 & ----- & -- & 6 & 7 & 8 & 9 & 10 & 11 & 12 & 13 & 14 & 15 & 16 & 17 & 18 & 19 & 20 & 21 & 22 \\
\hline $55.2(8)$ & 18.4 & ----- & -- & -- & -- & 8 & 9 & 10 & 11 & 12 & 13 & 14 & 15 & 16 & 17 & 18 & 19 & 20 & 21 & 22 \\
\hline $75.8(11)$ & 19.3 & ----- & -- & -- & -- & -- & -- & -- & -- & 12 & 13 & 14 & 15 & 16 & 17 & 18 & 19 & 20 & 21 & 22 \\
\hline $101.3(14.5)$ & 20.3 & ----- & -- & -- & -- & -- & -- & -- & -- & -- & -- & 14.5 & 15 & 16 & 17 & 18 & 19 & 20 & 21 & 22 \\
\hline $131+(19+)$ & $21.1+$ & ----- & -- & -- & -- & -- & -- & -- & -- & -- & -- & ----- & -- & -- & -- & -- & 19 & 20 & 21 & 22 \\
\hline
\end{tabular}

\subsection{Preliminary Results and Discussion}

Figure 9 is a screen shot of an ideal bubble point test. The raw DPT signal across the screen, the liquid screen side temperature (SD1), bulk liquid temperature (SD11), and RD ullage pressure during a run of six successive controlled breakthroughs for a $450 \times 2750$ using $\mathrm{GHe}$ in $\mathrm{LH}_{2}$ are shown. Breakthrough pressures occurred at roughly 90 to 95 percent of the maximum DPT signal. As shown, screen side and bulk liquid temperature gradually rose as ullage pressure was increased. Good signal to noise (SNR) ratio was also achieved, even in warmer liquid temperatures as the DPT signals decreased due to decreased surface tension of the liquid.

The low baseline bubble point value for $\mathrm{LH}_{2}$ using a $325 \times 2300$ screen is only $520 \mathrm{~Pa}$. The easiest way to improve upon this low reference value is to use a finer mesh. Figure 10 plots bubble point pressures taken at saturated or near saturated liquid states using GHe for the $325 \times 2300$ and $450 \times 2750$ screens. The solid lines are predictions based on Equation (2). "Near saturation" is defined as $\left(P_{\text {SCREEN }}-P_{\text {SAT }}\right) \leq 2.0$ psi. Higher bubble points are obtained using the finer 450 mesh screen, with an increase in 27 percent margin over the baseline 325 screen. While the model qualitatively agrees with the data, it under predicts the data (model predicts lower bubble point pressure) for both meshes, even for saturated liquid states where the theory is in best agreement. Since the data is taken at $20 \mathrm{~K}$ and the curves are based on room temperature bubble point tests, the pore diameter is clearly temperature dependent. Comparing the difference between data and model, the $325 \times 2300$ pore diameter achieves a 7 percent gain in bubble point and a 9 percent gain for the $450 \times 2750$ screen at $20 \mathrm{~K}$ over the model curve using the room temperature pore diameter. Figure 10 also implies that the $450 \times 2750$ screen may deliver a higher flow rate from a flight propellant tank over the $325 \times 2300$ screen. 


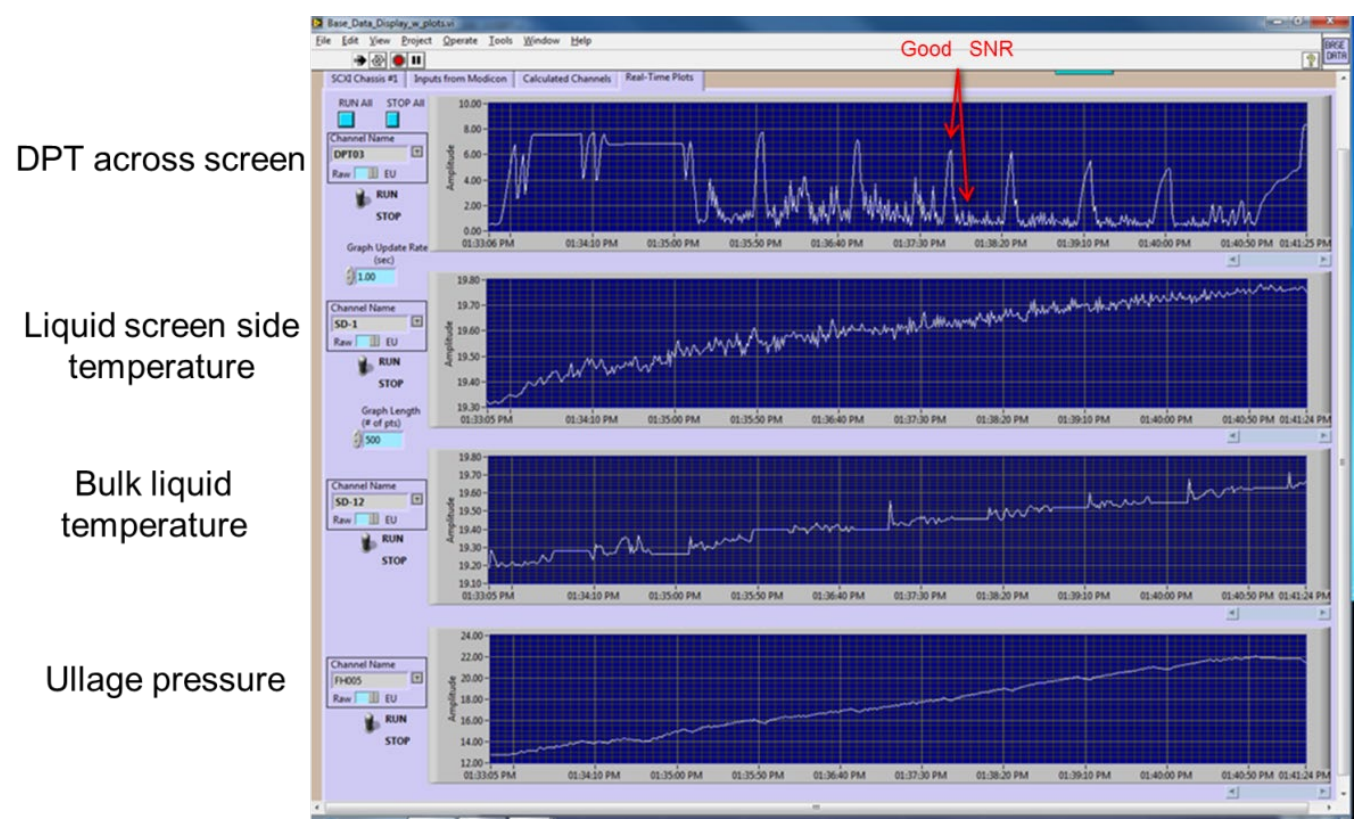

Figure 9.-Screenshot of an ideal test run during $450 \times 2750 \mathrm{GHe} / \mathrm{LH}_{2}$ testing.

The second way to improve upon the low reference bubble point value is to directly increase the surface tension of the liquid. Figure 11 plots $\mathrm{LH}_{2}$ bubble point data as a function of the liquid side screen temperature, SD1. Again, only bubble points taken in saturated or near saturated liquid states are plotted to permit direct comparison between screen meshes. As shown for both meshes, higher bubble points are always achieved in colder liquid temperatures, since surface tension is an inverse function of temperature. Model and data are again in qualitative agreement when surface tension is based on SD1, but not the bulk liquid temperature SD11. Screen pores could be shrinking at colder liquid temperature due to the thermal coefficient of contraction of the warp and shute wires. Because the gain is different for each screen, geometrical considerations of the actual pore structure must also be taken into account. Nonetheless, extra margin is obtained for both meshes at cryogenic hydrogen temperatures.

Finally, the third method to improve upon the low reference bubble point value is to indirectly raise the surface tension of the liquid. Figure 12 plots all of the $325 \times 2300$ bubble point data obtained with both $\mathrm{GHe}$ and $\mathrm{GH}_{2}$ as pressurant gases. The solid line is the model prediction using a room temperature pore diameter. Several trends are obvious. First, GHe outperforms $\mathrm{GH}_{2}$ across the entire range of $\mathrm{LH}_{2}$ temperatures, and the disparity between gases is far outside the uncertainty in the data. Compared to trends with $\mathrm{LOX}$ and $\mathrm{LCH}_{4}$ from Hartwig et al. (2012) and Hartwig and McQuillen (2012b) this disparity in performance between pressurization gases is greatest at the coldest $\mathrm{LH}_{2}$ temperatures. Second, while data and theory are in qualitative agreement, the room temperature pore diameter model underpredicts $\mathrm{GHe}$ data and overpredicts the $\mathrm{GH}_{2}$ data. Therefore, noncondensible pressurization increases margin for the bubble point, but autogenous pressurization decreases margin for the bubble point, relative to the model predicted curves. Difference in performance between the two pressurization schemes were explained previously in Hartwig et al. (2012) and Hartwig and McQuillen (2012b). In summary, during autogenous pressurization, vapor condenses across the screen into the liquid, warming the liquid at the screen, reducing the surface tension and thus the bubble point. Meanwhile pressurization with the noncondensible GHe causes liquid to evaporate away from the screen cooling the liquid temperature at the screen, increasing surface tension and thus the bubble point. 


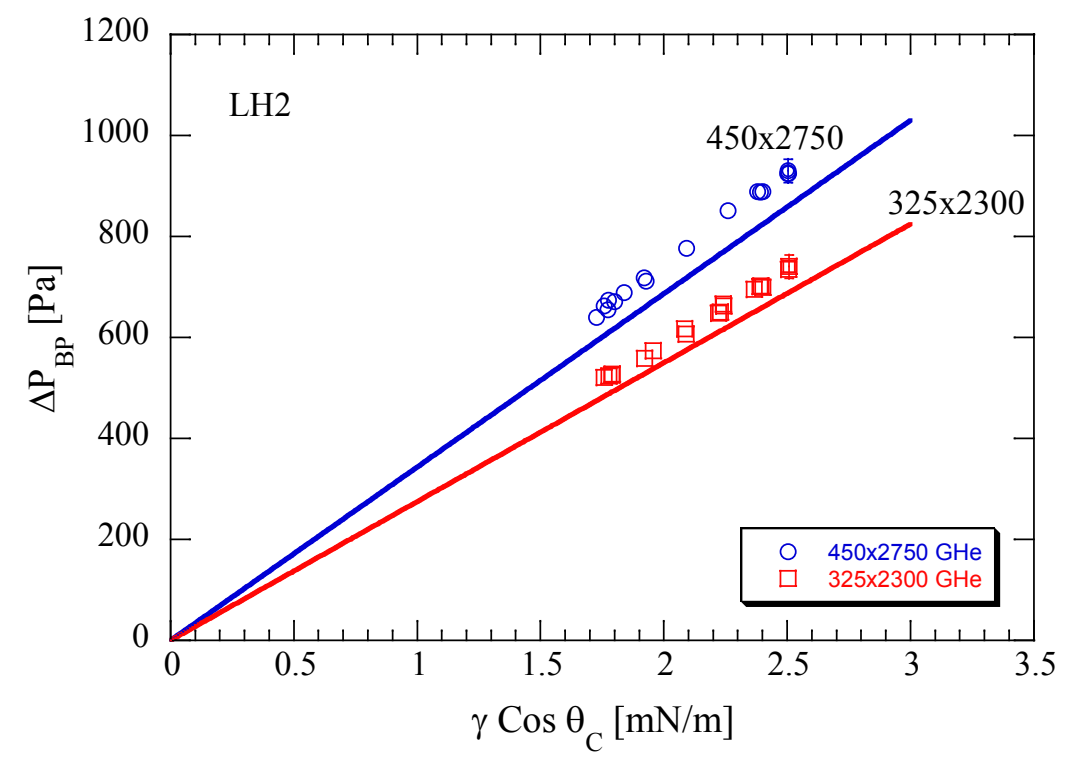

Figure 10.-Liquid hydrogen bubble point as a function of screen mesh. Solid lines are model predictions based on Equation (1) using room temperature pore diameters.

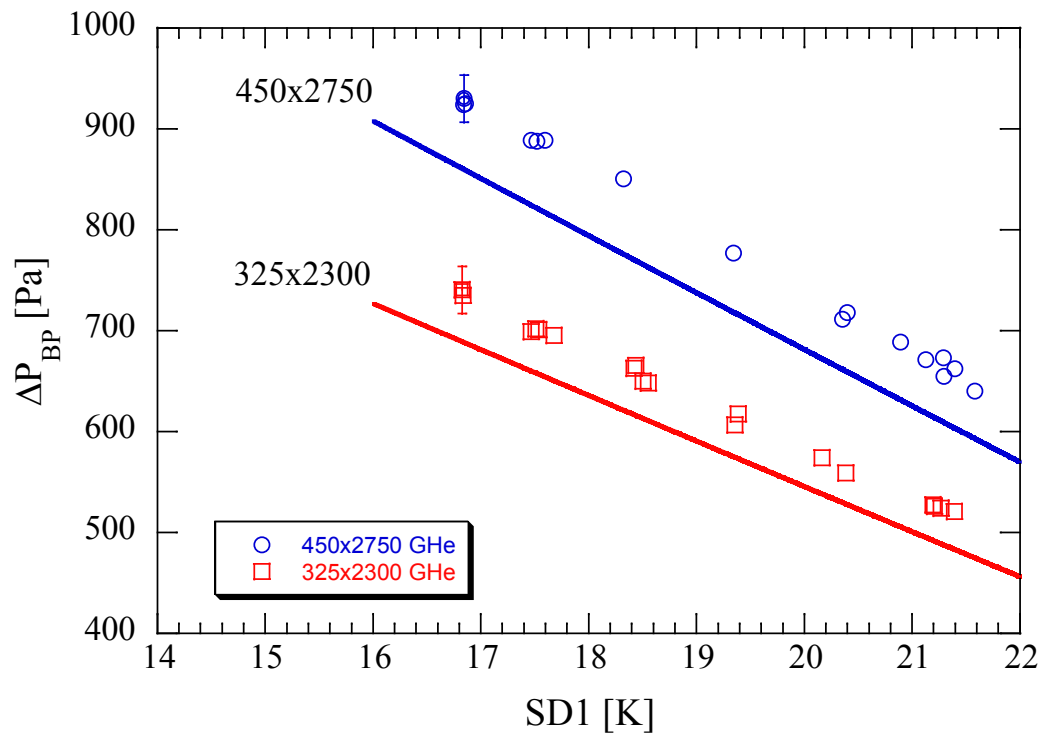

Figure 11.-Liquid hydrogen bubble point as a function of liquid screen side temperature (SD1). Solid lines are model predictions based on Equation (1) evaluated using room temperature pore diameters. 


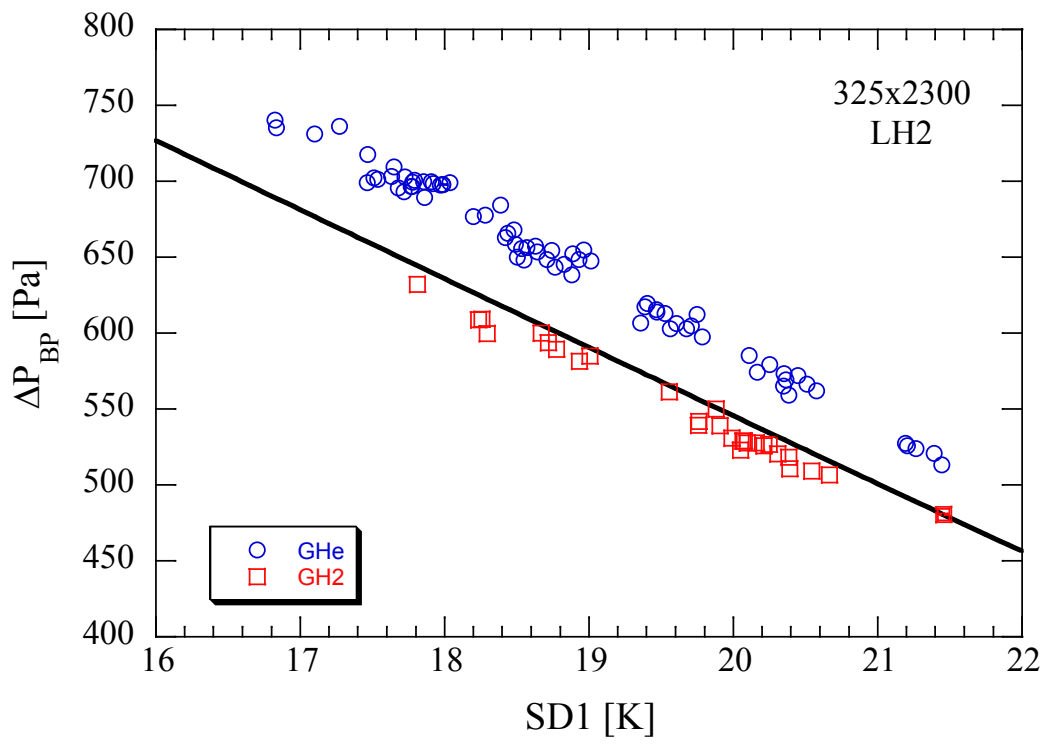

Figure 12.-Liquid hydrogen bubble point as a function of pressurization gas for the $325 \times 2300$ screen. The solid line is the model prediction based on Equation (1) evaluated using a room temperature pore diameter.

Trends here are in excellent agreement with previous bubble point tests in $\mathrm{LOX}$ and $\mathrm{LCH}_{4}$ where similar disparity in performance existed between the autogenous and noncondensible pressurization methods (Hartwig et al. 2012 and Hartwig and McQuillen 2012a). Unlike LOX and $\mathrm{LCH}_{4}$ test results however, disparity between $\mathrm{GH}_{2}$ and $\mathrm{GHe}$ in $\mathrm{LH}_{2}$ is far outside experimental uncertainty. Analysis of the test data for $\mathrm{LOX}, \mathrm{LCH}_{4}$, and $\mathrm{LH}_{2}$ shows that this disparity increases as the saturation temperature decreases, with the most pronounced difference at $\mathrm{LH}_{2}$ temperatures. On average, GHe data is 13 percent higher than the $\mathrm{GH}_{2}$ data for the $325 \times 2300$ screen.

In light of the apparent under prediction of the GHe data, Equation (1) may still be used as a lower bound to predict screen channel LAD performance for a flight $\mathrm{LH}_{2}$ system using helium pressurization, since the actual breakdown pressure is higher for all liquid temperatures tested here. As stated earlier, the bubble point represents the maximum allowable pressure drop before gas or vapor is ingested into the channel and transfer line to an engine or receiver depot tank. Therefore, Figure 12 implies that using GHe to pressurize and/or subcool a flight $\mathrm{LH}_{2}$ propellant tank during expulsion results in higher margin in the total allowable pressure loss for the LAD. Higher bubble point pressures can translate into higher flow rates to the engine or receiver depot tank.

\subsection{Future Work}

Future plans include parametric analysis of $325 \times 2300,450 \times 2750$, and $510 \times 3600$ bubble point data in both $\mathrm{LH}_{2}$ and $\mathrm{LN}_{2}$ to thoroughly examine the effect of liquid temperature and pressure and type of pressurization gas on the bubble point pressure. In addition, heated pressurant gas data will also be analyzed to determine how warm gas affects LAD performance. Full scale LAD outflow tests are also planned, and these tests will examine the various pressure loss terms from Equation (3).

\subsection{Conclusion}

A fully robust system has been designed and characterized to examine the effect of screen mesh, liquid temperature and pressure, and pressurization type and temperature on the primary performance parameter for screen channel liquid acquisition devices, the bubble point. Data has been collected for 
three different fine mesh screen channel liquid acquisition device samples in liquid hydrogen over thermal conditions representative of a low pressure $\mathrm{LH}_{2}$ propellant tank. Preliminary results obtained here in $\mathrm{LH}_{2}$ are in qualitative agreement with previous test results using liquid oxygen and methane.

The low bubble point of the $325 \times 2300$ screen hinders the operating range over which single phase liquid may be extracted from an $\mathrm{LH}_{2}$ propellant tank. By using the finer $450 \times 2750$ screen, operating at a colder liquid temperature, and pressurizing the system with a noncondensible pressurant, such as gaseous helium, a higher margin in the bubble point pressure is achieved over the $325 \times 2300$, thus potentially increasing the total allowable flow rate from a liquid hydrogen fuel depot. Bubble points in excess of $900 \mathrm{~Pa}$ are achievable with the $450 \times 2750$ mesh, which represents a 170 percent increase over the baseline NBP value for a $325 \times 2300$ screen. Results indicate that Equation (1) using a room temperature pore diameter can be used as a lower bound to predict the GHe bubble point pressure across the full range of temperatures representative of a flight $\mathrm{LH}_{2}$ propellant tank. For all screens and temperatures tested, pressurization with GHe outperformed pressurization with $\mathrm{GH}_{2}$. Compared to test results in other propellants, the disparity in performance between the noncondensible and autogenous pressurization schemes is greatest at $\mathrm{LH}_{2}$ temperatures. Results here have direct impact on future LAD and pressurization system design for low surface tension liquids, especially future cryogenic hydrogen fueled depots.

\section{References}

Anderson, J.E., (1989) “Superfluid Helium Acquisition System Development," Cryogenics 29, pp. 513-516. Anglim, D.D., (1981) "Space Shuttle Aft Propulsion Subsystem” AIAA-81-1511.

Burge, G.W., and Blackmon, J.B. (1973) "Study and Design of Cryogenic Propellant Acquisition Systems-Volume II-Supporting Experimental Program,” NAS8-27685 MDAC Report MDC G5038.

Burge, G.W., Blackmon, J.B., and Castle, J.N. (1973) "Design of Propellant Acquisition Systems for Advanced Cryogenic Space Propulsion Systems" AIAA/SAE Propulsion Conference Las Vegas, NV, Nov. 5-7, 1973.

Cady, E.C. (1973) "Study of Thermodynamic Vent and Screen Baffle Integration for Orbital Storage and Transfer of Liquid Hydrogen-Final Report," NASA CR-134482.

Cady, E.C., (1975) "Design and Evaluation of Thermodynamic Vent/Screen Baffle Cryogenic Storage System," NASA CR-134810.

Cady, E.C., (1977) "Effect of Transient Liquid Flow on Retention Characteristics of Screen Acquisition Systems," NASA CR-135218.

Castle, J.N., (1972) "Heat Transfer Effects on Bubble Point Tests in Liquid Nitrogen,” MDC02653 McDonnell Douglas Astronautics Company, Huntington Beach, CA.

Chato, D.J., and Kudlac, M.T. (2002) "Screen Channel Liquid Acquisition Devices for Cryogenic Propellants," AIAA-75-1196, 38th Joint Propulsion Conference and Exhibit Indianapolis, IN, July 7-10, 2002.

Fester, D.A., Villars, A.J., and Uney, P.E. (1975) "Surface Tension Propellant Acquisition System Technology for Space Shuttle Reaction Control Tanks," AIAA-75-1196, 11th AIAA/SAE Propulsion Conference, Anaheim, CA, Sept. 29-Oct. 1, 1975.

Hartwig, J.W., and Mann, J.A. (2013a) "A Simplified Model for Predicting the Breakdown Point of Screen Channel Liquid Acquisition Devices," AiCh Journal (submitted for publication).

Hartwig, J.W., and Mann, J.A. (2013b) "Bubble Point Pressures of Binary Methanol/Water Mixtures," AiCh Journal (submitted for publication).

Hartwig, J.W., and McQuillen, J. (2011) "Analysis of Screen Channel LAD Bubble Point Tests in Liquid Oxygen at Elevated Temperature," 41nd AIAA Thermophysics Conference, Jun. 27-30, 2011, Honolulu, HI.

Hartwig, J.W., and McQuillen, J. (2012a) "Analysis of Screen Channel LAD Bubble Point Tests in Liquid Methane at Elevated Temperature" 50th Aerospace Sciences Meeting, Jan. 9-12, 2012, Nashville, TN. 
Hartwig, J.W., and McQuillen, J. (2012b) "Screen Channel LAD Bubble Point Tests in Liquid Methane," Journal of Thermophysics and Heat Transfer (submitted for publication).

Hartwig, J.W., McQuillen, J., and Jurns, J. (2012) "Screen Channel LAD Bubble Point Tests in Liquid Oxygen," Journal of Thermophysics and Heat Transfer (submitted for publication).

Jaekle, D.E., (1991) "Propellant Management Device Conceptual Design and Analysis: Vanes," AIAA-91-2172.

Jaekle, D.E., (1993) "Propellant Management Device Conceptual Design and Analysis: Sponges," AIAA-93-1970.

Jaekle, D.E., (1997) "Propellant Management Device Conceptual Design and Analysis: Galleries," AIAA-97-2811.

Jurns, J.M., McQuillen, J.B., Gaby, J.D., and Sinacore S.A., "Bubble Point Measurements with Liquid Methane of a Screen Channel Capillary Liquid Acquisition Device," 54th JANNAF Conference, Denver, CO, May 14-17, 2007.

Kudlac, M.T., and Jurns, J.M. (2005) "Screen Channel Liquid Acquisition Devices for Liquid Oxygen," AIAA-2006-5054, 42nd Joint Propulsion Conference, Sacramento, CA, Jul. 9-12, 2005.

Kutter, B., (2010) "Propellant Depots Made Simple," FISO Presentation, Nov. 10, 2010.

Kutter, B., Zegler, F., O’Neil, G.O., and Pitchford, B. (2008) “A Practical, Affordable Cryogenic Propellant Depot Based on ULA's Flight Experience," AIAA Space Conference and Exposition, Sep. 9, 2009, San Diego, CA.

McLean, C., Mustafi, S., Walls, L., Pitchford, B., Wollen, M., and Schmidt (2011) "Simple, Robust Cryogenic Propellant Depot for Near Term Applications,” 2011 IEEE Aerospace Conference, Big Sky, MT.

Paynter, H.L., (1973) “Acquisition/Expulsion System for Earth Orbital Propulsion System, Vol. III, Cryogenic Test," Martin Marietta Corp., Denver, CO, MCR-73-97.

Peterson, R., and Uney, P. (1978) "Development and Qualification of the Space Shuttle Orbiter Reaction Control System Propellant Tank" AIAA-78-1026 AIAA/SAE 14th Joint Propulsion Conference, Las Vegas, NV, Jul. 25-27 1978.

Radcliffe, W.F., and Transue, J.R. (1961) "Problems Associated with Multiple Engine Starts in Spacecraft," American Rocket Society Journal.

Schweickert, T.F., (1981) "Design of the Aft Propulsion Subsystem for Long Life," JANNAF Propulsion Meeting, New Orleans, LA, May 26-28, 1981.

Van Dyke, M., (1998) "Identification of Influential Factors for Liquid Acquisition Device Designs," AIAA-98-3198. 



\begin{tabular}{|c|c|c|}
\hline \multicolumn{2}{|c|}{ REPORT DOCUMENTATION PAGE } & $\begin{array}{l}\text { Form Approved } \\
\text { OMB No. 0704-0188 }\end{array}$ \\
\hline \multicolumn{3}{|c|}{ 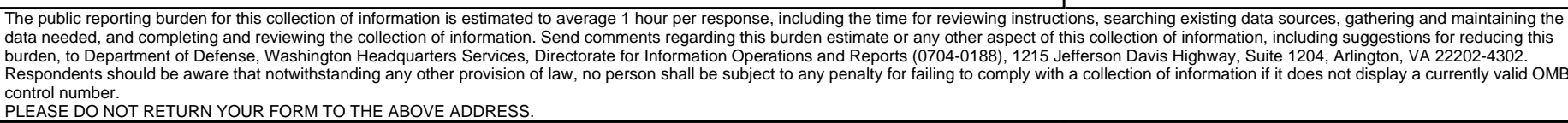 } \\
\hline $\begin{array}{l}\text { 1. REPORT DATE (DD-MM-YYYY) } \\
01-02-2013\end{array}$ & $\begin{array}{l}\text { 2. REPORT TYPE } \\
\text { Technical Memorandum }\end{array}$ & 3. DATES COVERED (From - To) \\
\hline \multirow{3}{*}{\multicolumn{2}{|c|}{$\begin{array}{l}\text { 4. TITLE AND SUBTITLE } \\
\text { Performance Gains of Propellant Management Devices for Liquid Hydrogen Depots }\end{array}$}} & 5a. CONTRACT NUMBER \\
\hline & & 5b. GRANT NUMBER \\
\hline & & 5c. PROGRAM ELEMENT NUMBER \\
\hline \multirow{3}{*}{\multicolumn{2}{|c|}{$\begin{array}{l}\text { 6. AUTHOR(S) } \\
\text { Hartwig, Jason, W.; McQuillen, John, B.; Chato, David, J. }\end{array}$}} & 5d. PROJECT NUMBER \\
\hline & & 5e. TASK NUMBER \\
\hline & & $\begin{array}{l}\text { 5f. WORK UNIT NUMBER } \\
\text { WBS } 645454.01 .04\end{array}$ \\
\hline \multicolumn{2}{|c|}{$\begin{array}{l}\text { 7. PERFORMING ORGANIZATION NAME(S) AND ADDRESS(ES) } \\
\text { National Aeronautics and Space Administration } \\
\text { John H. Glenn Research Center at Lewis Field } \\
\text { Cleveland, Ohio 44135-3191 }\end{array}$} & $\begin{array}{l}\text { 8. PERFORMING ORGANIZATION } \\
\text { REPORT NUMBER } \\
\text { E-18587 }\end{array}$ \\
\hline \multirow{2}{*}{\multicolumn{2}{|c|}{$\begin{array}{l}\text { 9. SPONSORING/MONITORING AGENCY NAME(S) AND ADDRESS(ES) } \\
\text { National Aeronautics and Space Administration } \\
\text { Washington, DC 20546-0001 }\end{array}$}} & $\begin{array}{l}\text { 10. SPONSORING/MONITOR'S } \\
\text { ACRONYM(S) } \\
\text { NASA }\end{array}$ \\
\hline & & $\begin{array}{l}\text { 11. SPONSORING/MONITORING } \\
\text { REPORT NUMBER } \\
\text { NASA/TM-2013-217834 }\end{array}$ \\
\hline \multicolumn{3}{|c|}{$\begin{array}{l}\text { 12. DISTRIBUTION/AVAILABILITY STATEMENT } \\
\text { Unclassified-Unlimited } \\
\text { Subject Categories: } 20,28 \text {, and } 34 \\
\text { Available electronically at http://www.sti.nasa.gov } \\
\text { This publication is available from the NASA Center for AeroSpace Information, 443-757-5802 }\end{array}$} \\
\hline
\end{tabular}

\section{ABSTRACT}

This paper presents background, experimental design, and preliminary experimental results for the liquid hydrogen bubble point tests conducted at the Cryogenic Components Cell 7 facility at the NASA Glenn Research Center in Cleveland, Ohio. The purpose of the test series was to investigate the parameters that affect liquid acquisition device (LAD) performance in a liquid hydrogen ( $\mathrm{LH}_{2}$ ) propellant tank, to mitigate risk in the final design of the LAD for the Cryogenic Propellant Storage and Transfer Technology Demonstration Mission, and to provide insight into optimal LAD operation for future $\mathrm{LH}_{2}$ depots. Preliminary test results show an increase in performance and screen retention over the low reference $\mathrm{LH}_{2}$ bubble point value for a $325 \times 2300$ screen in three separate ways, thus improving fundamental $\mathrm{LH} 2$ LAD performance. By using a finer mesh screen, operating at a colder liquid temperature, and pressurizing with a noncondensible pressurant gas, a significant increase in margin is achieved in bubble point pressure for $\mathrm{LH}_{2}$ screen channel LADs.

\section{SUBJECT TERMS}

Cryogenic fluids; Cryogenics; Bubbles; Helium; Interfacial tension; Cryogenic fluid management; Liquid acquisition devices; Liquid hydrogen; Pore diameter; Contact angle

\begin{tabular}{|c|c|c|c|c|c|}
\hline \multicolumn{3}{|c|}{ 16. SECURITY CLASSIFICATION OF: } & \multirow{2}{*}{$\begin{array}{l}\text { 17. LIMITATION OF } \\
\text { ABSTRACT } \\
\text { UU }\end{array}$} & \multirow{2}{*}{$\begin{array}{l}\text { 18. NUMBER } \\
\text { OF } \\
\text { PAGES } \\
24\end{array}$} & \multirow{2}{*}{$\begin{array}{l}\text { 19a. NAME OF RESPONSIBLE PERSON } \\
\text { STI Help Desk (email:help@sti.nasa.gov) } \\
\text { 19b. TELEPHONE NUMBER (include area code) } \\
\text { 443-757-5802 }\end{array}$} \\
\hline $\begin{array}{l}\text { a. REPORT } \\
U\end{array}$ & $\begin{array}{l}\text { b. ABSTRACT } \\
\mathrm{U}\end{array}$ & $\begin{array}{l}\text { c. THIS } \\
\text { PAGE } \\
\text { U }\end{array}$ & & & \\
\hline
\end{tabular}



